\title{
Ozone Correction for AM0 Calibrated Solar Cells for the Aircraft Method
}

\author{
David Snyder, NASA GRC, \\ David Scheiman and Phillip Jenkins, OAI
}

The aircraft solar cell calibration method has provided cells calibrated to space conditions for 37 years. However, it is susceptible to systematic errors due to ozone concentration in the stratosphere. The present correction procedure applies a $1 \%$ increase to the measured Isc values. High band-gap cells are more sensitive to ozone adsorbed wavelengths so it has become important to reassess the correction technique. This paper evaluates the ozone correction to be $1+\{\mathrm{O} 3\}^{\star} \mathrm{Fo}$, where $\mathrm{Fo}$ is $29.5 \times 10^{-6} / \mathrm{d}$.u. for a Silicon solar cell and $42.2 \times 10^{-6} / \mathrm{d}$.u. for a GaAs cell. Results will be presented for high band-gap cells. A comparison with flight data indicates that this method of correcting for the ozone density improves the uncertainty of AM0 Isc to $0.5 \%$. 
Contact:

David B. Snyder

NASA Glenn Research Center

MS 302-1

21000 Brookpark Rd.

Cleveland, $\mathrm{OH} 44135$

Phone: (216)433-2217

Fax: (216)433-6106

david.b.snyder@grc.nasa.gov

Catagory: $3 b$

Prefer Oral Presentation

Title: Ozone Correction for AMO Calibrated Solar Cells for the Aircraft Method

Authors:

David B. Snyder

NASA Glenn Research Center

MS 302-1

21000 Brookpark Rd.

Cleveland, OH 44135
David A. Scheiman and Phillip P. Jenkins

OAI

NASA Glenn Research Center

MS 302-1

21000 Brookpark Rd.

Cleveland, $\mathrm{OH} 44135$

\section{Introduction}

The NASA GRC aircraft calibration method has been in use for 37 years and has provided the aerospace industry with cells calibrated to orbital conditions. The method measures the Isc, short circuit current, at AM0, air mass zero, for setting solar simulators to space conditions during ground-based measurements. This method has an accuracy of $1 \%$ for Silicon cells based on the standard deviation of the measurements and a comparison with balloon and shuttle measurements [ref 1].

The method is susceptible to a systematic error due to the nonuniform distribution of ozone in the atmosphere. This error is presently accommodated by multiplying the measured Isc(AM0) by an ozone correction factor of 1.01 based on calculations for Silicon cells [ref 1].

However, cell technologies have changed and higher band-gap materials are becoming more important, particularly in multi-junction cells. These cells will be more sensitive to changes in the ozone adsorbed portions of the spectrum. Also, daily ozone measurements have become available from the Earth Probe TOMS (Total Ozone Mapping Spectrometer) [ref 2]. Both reasons make it important to reassess and improve to the procedure for ozone correction in the aircraft calibration method.

The revised procedure consists of two steps. First, the cell spectral response function is integrated with the solar irradiance spectrum and an ozone corrected irradiance spectrum the two results are compared to provide $F o$, the correction per unit ozone column density, for the appropriate cell technology. Second, an ozone correction factor is calculated from the measured ozone density using $F o$ and applied to the extrapolated value from a Langley plot. 
Figure 1. Ozone Corrected Irradiance.

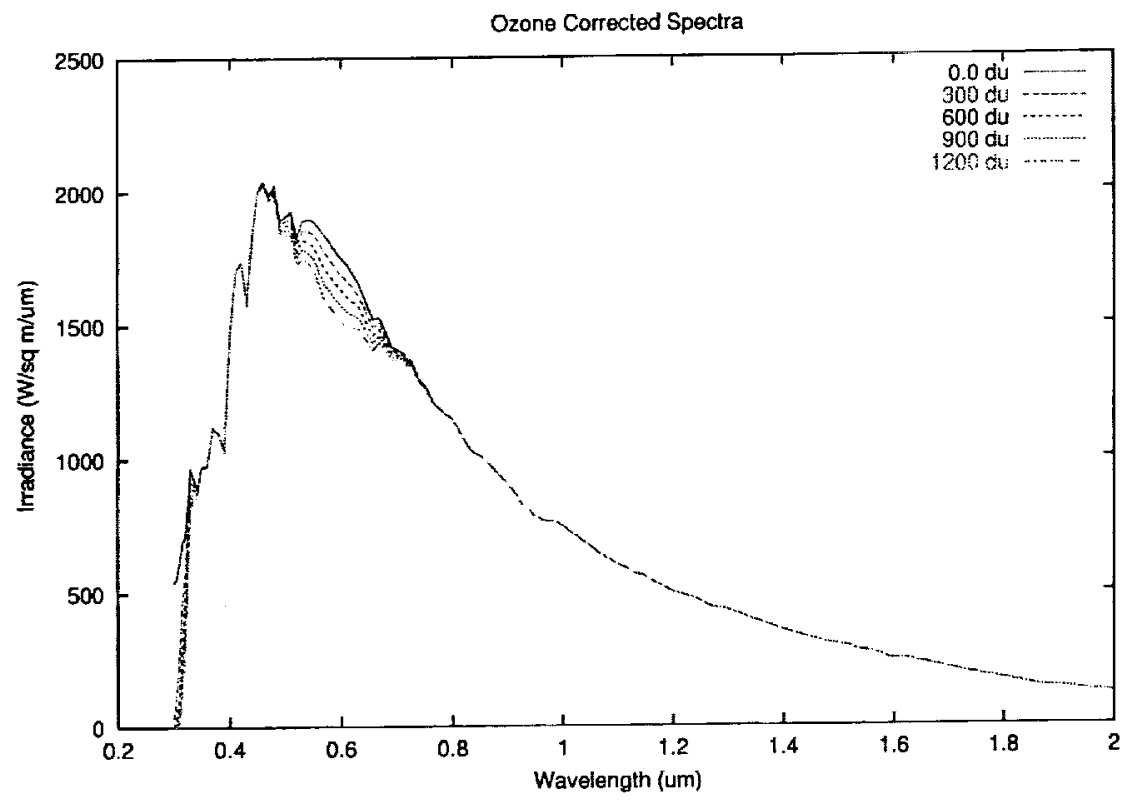

\section{Model}

As a basis for obtaining ozone adsorption corrected spectra, the Simple Solar Spectral Model (SSSM) from NREL was used [ref 3]. The Langley Plot technique used by the Aircraft Calibration Method to extrapolate to orbit contition corrects for adsorption processes that are proportional to pressure. Since data is taken above the tropopause, the water and dust of the troposphere is not of concern. But since most of the ozone is concentrated in a layer above the data acquisition region, this correction must be included in the spectrm. The irradiance as a function of wavelength is given by:

$$
I(\lambda)=H o(\lambda) \exp (-a o(\lambda)\{03\}),
$$

where $H o$ is the extraterrestrial irradiance at 1.0 au from the sun, $a o$, is the ozone adsorption coefficient as a function of wavelength, and, $\{03\}$, is the ozone column density along the optical path. The ozone adsorption coefficients are those in SSSM. Figure 1 shows the irradiance for five ozone column densities given in Dobson Units, atm-millicentimeters.

Two standard cells that have been frequently flown are A-161 a Silicon cell, and A-133 a GaAs cell. Spectral response functions at $20 \mathrm{~nm}$ intervals are available for these cells and were convoluted with the irradiance spectra to calculate Isc as a function of Ozone column density. The ozone correction factor, Fo, is obtained from $(\operatorname{Isc}(0) / I s c(\{\mathrm{O} 3\})-1) /\{\mathrm{O} 3\}$.

\begin{tabular}{|c|c|c|}
\hline $\begin{array}{c}\text { Ozone Column } \\
\text { Density, \{O3\} (du) }\end{array}$ & $\begin{array}{c}\text { Isc(A-161) } \\
\text { mA/sq-cm }\end{array}$ & $\begin{array}{c}\text { Isc(A-133) } \\
\text { mA/sq-cm }\end{array}$ \\
\hline 0 & 41.220 & 29.279 \\
\hline 600 & 40.499 & 28.558 \\
\hline 1200 & 39.809 & 27.867 \\
\hline Fo (Jdu) & $29.54 \times 10^{-6}$ & $42.21 \times 10^{-6}$ \\
\hline
\end{tabular}

\section{Application to Flight Data}

A-161 was flown 20 times during the 2000/2001 flying season. It had an average Isc of $165.59 \pm 0.81$ ma. A-133 was flown 15 times over the 1999-2000 and 2000/2001 flying seasons. It had an average Isc of $106.4 \pm 0.87 \mathrm{ma}$. 
Daily Ozone densities were obtained from the Earth Probe TOMS web site [ref 4] for

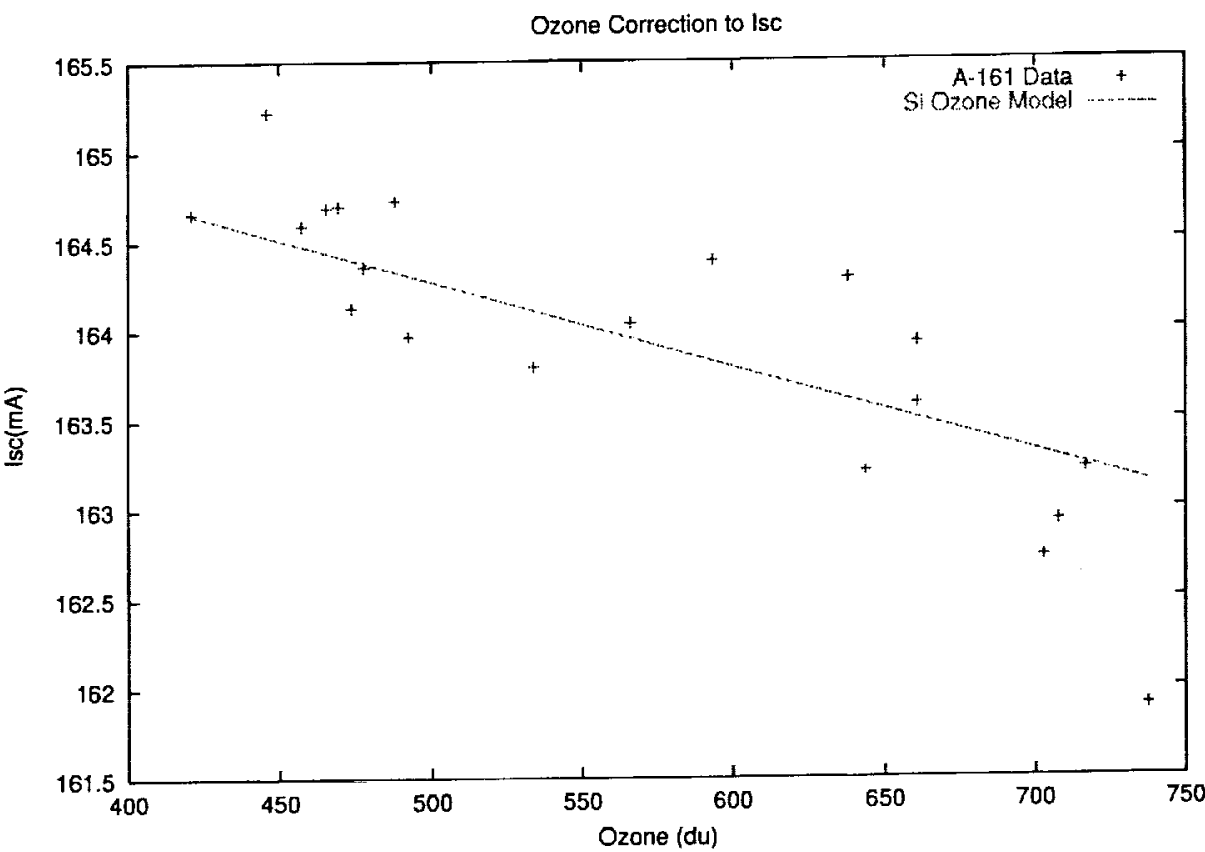

$45 \mathrm{~N} 85 \mathrm{~W}$, a position along the flight path [ref 1]. From Table A. 1 of reference 2 , about $80 \%$ to $85 \%$ of the ozone is above the top of flight profile, 120 $\mathrm{mb}$. The Ozone column density will be estimated as $0.83^{\star} \mathrm{On} / \cos (\mathrm{Z})$ where $O n$ is the reported Ozone Number for $45 \mathrm{~N}$ $85 \mathrm{~W}$ and $Z$ is the zenith angle.

Figure 2. Comparison of A-161 flight data with Silicon cell ozone correction model.

Figure 2 shows the Langley plot evaluated Isc for A-161 for the 2000-2001 season plotted against the ozone column density. Applying the model to each of the Isc measurements gives an $I s c(A-161)=166.70 \pm 0.47$. The model curve is $166.70 /\left(1+F s i^{*}\{03\}\right)$. The reduction of the standard deviation of the measurements by a factor of 2 suggests that this is a important contribution to the analysis. For the GaAs cell, A-133, Isc $=107.85 \pm 0.66$. Again, analysis results in a significant improvement in the annual scatter of the data.

\section{Summary}

This extended abstract illustrates an improved technique for correcting for ozone adsorption in the stratosphere. The technique has been demonstrated for Si and GaAs cells. The paper will also include data from InGaP cells.

\section{References}

[1] Phillip Jenkins, David Brinker, and David Scheiman, "Uncertianty analysis of high altitude aircraft air mass zero solar cell calibration", V26-206, 26th PVSC; Sept 30-Oct.3, 1997; Anaheim, CA, IEEE 0-7803-3767-0/97.

[2] McPeters, R.D. et al, Earth Probe Total Ozone Mapping Spectrometer (TOMS) Data Products Users Guide, NASA TP 1998-206895 (1998).

[3] Bird, R., and Riordan, C., Simple Solar Spectral Model for Direct and Diffuse Irradiance on Horizontal and Tilted Planes at the Earth's Surface for Cloudless Atmospheres, SERI/TR-215-2436, December 1984.

[4] <http://toms.gsfc.nasa.gov/eptoms/ep.html>. 